\title{
Towards sustainable innovations - essay in memoriam of Andries Nentjes
}

\section{Yoram KROZER}

\section{Sustainable Innovations Academy, Amsterdam, Netherlands, Graz University of Technology, Austria}

\begin{abstract}
:
Aim: This paper assesses theoretically and empirically three key factors for sustainable development within context of debates about economy and environment: autonomous technological change, induced technological change and barriers of entry to innovations.

Design/research methods: The paper covers a literature review on strong versus weak sustainability, followed by an explanation of autonomous technological change. Statistical analysis with literature review on induced technological change due to consumers' and policy demands for sustainable innovations, as well as literature review on policy support for the incumbent interests that rival sustainable innovations is provided. The information used is largely based on two chapters in the book on sustainable innovations (Krozer 2015), and presented in the context of long scientific cooperation with the late Andries Nentjes.

Conclusion/findings: The economic theoretical debates are hardly relevant for policies on sustainable innovations, because political views are inconsistent with observations and change during fluctuations in economic outcomes. The main conclusion is that autonomous technological change is the driver of sustainable innovations. Present policies pose barriers of entry to sustainable innovations, where the global value of support for vested interest exceeds the market potential for induced technological change due to demands of policies and consumers put together.
\end{abstract}

Originality/value of the paper: The study contribution to understanding of autonomous and induced technological change, showing that shifting policy support away from the incumbent interests towards sustainable innovations is key for sustainable development.

Keywords: sustainable innovations, income, environment, consumers, business support.

JEL: O00, O30, O31, O32, O55, Q01

Correspondence address: Yoram KROZER. Yoram Krozer, Iepenplein 44, 1091JR Amsterdam, Netherlands. E-mail: krozer@xs4all.nl.

Received: 14.11.2020, Revised: 17.12.2020, Accepted: 18.12.2020

doi: http://dx.doi.org/10.29015/cerem.903 


\section{Introduction}

This paper discusses drivers of innovations that generate income growth and maintain availability of environmental qualities. Such sustainable innovations refer to renewable energy, organic agriculture, agroforestry, recycling and other businesses based on cleaner technologies which generate profits and foster environmental qualities. Andries Nentjes was a trailblazer in assessing those drivers. Using his economic model it can be shown that income growth is compatible with environmental qualities if authorities prevent pollution through regulations, because polluters have no interest to reduce their negative environmental impacts. This conclusion was published in 1973 (Kuipers, Nentjes 1973), nearly fifteen years before the popularization of the term sustainable development by the World Commission on Environment and Development (WCED 1987). Thereafter, Andries Nentjes promoted innovations for sustainable development in his advises to politicians, businesses and civil organizations, along with theorizing about policies on the sustainable innovations (Krozer, Nentjes 2006) as well as the possibilities for such innovations in businesses (Krozer, Nentjes 2008).

Our viewpoints complemented each other. While Andries Nentjes expected that authorities are drivers of change for sustainable development, my assessment was more cautious about their role and more optimistic about the role of innovating social entrepreneurs and ethical consumers that demand far reaching pollution reduction. He expressed the conventional economist opinion that markets fail to maintain environmental qualities because these common goods are difficult to appropriate, and therefore, private interests have little incentives to reduce pollution. Hence, authorities should correct this market failure through policies that maintain availability of environmental qualities, while ensuring welfare growth. This line of thought assumes that the authorities deliberate various societal interests for a common good rather than pursue interests of political elites, firms and other private groups that seek rents from the monopoly power of the authorities. My perspective as a practitioner in business referred to policy failures, such as financial support for the polluting businesses creating barriers of entry for innovators. Such support of incumbent interests is not justifiable from the welfare perspective, and rival to the sustainable innovations. Emerging innovators with social responsibilities were 
obstructed when authorities entitled those incumbents for decisions about education, science, environment, and other common goods. In practice, both viewpoints are valid and their relevance varies depending on cultural traditions and political constellations.

Herewith, the policy failures are addressed because the ideas about market failures regarding the creation of common goods are part and parcel in economic theories. For decades it has been observed that entitling private interests for decision making about the common goods strengthens rent-seeking behavior of businesses, entailing clientelism and corruption, which undermine competition and welfare (Krueger 1974). Policy support of vested businesses in the past undermined economic development, due to barriers of entry for newcomers that deliver superior qualities or lower prices, as well as barriers of entry for innovators (Murphy et al. 1993). This support of incumbent interests can include non-financial licenses, property rights, concession for resources, monopoly land use, patents, author rights and other regulations, as well as financial policy instruments such as subsidies, tax exemptions, credit facilities, bonds, price discounts and other monetary gains for the existing businesses (Boldrin, Levine 2004). In environmental policies, rent-seeking behavior is widely observed when the polluting firms are licensed to operate. Moreover, polluting business are often entitled to arrangements in voluntary agreements (covenants), which undermines democratic decisions, obstructs the rule of law, and impedes sustainable innovations because of undemanding pollution reduction and fail-soft enforcement (Ashford 1996). Such agreements persist despite failures to attain sealed arrangements, because it is convenient for the authorities to shift their responsibilities for environmental qualities to market parties that aim to postpone or avoid pollution reduction. In addition, the authorities' policies are myopic when long-term interests of the common goods are subordinated to shortterm private gains.

The general question addressed in this paper is what factors generate sustainable innovations from a global perspective. In answering that general question, four subquestions are dealt with in subsequent sections. First, the ideological context of drivers for sustainable innovations is presented. Second, the role of knowledge in generating autonomous technological change along with pollution reduction, i.e., 
changes without direct policy interventions, is elaborated. Third, the role of policy demands and consumers demands for the sustainable innovations, i.e., induced technological change, is discussed. Finally, the role of financial policy support for the incumbent businesses is analysed. Non-monetary support is not dealt with in this paper. The basis of this article in my book on theory and practice of sustainable development (Krozer 2015). The discussion reflects an important aspect of a longlasting scientific discussion with the late Andries Nentjes.

A few definitions help to avoid misunderstandings. Following Sen (2009), welfare is defined in a broad sense as a common good of satisfying individual and social demands from an intra- and inter-generational perspective, through the generation and distribution of wealth, leisure, care and other values. Added to this, an important element is the decision making about these values across generations, sexes and races. All within the limit of existing scarce resources. Innovations are comprehended in line with Schumpeter's view (1989: 59) as "doing things differently" with reference to novel technologies, products, services, designs, images, models or other objects for profits. Their qualification as sustainable refers to substantial reduction of pollution. Pollution is considered in a broad sense as impacts that undermine availability of the natural resources, diversity of nature and landscape, health and quality of life of people. The incumbent interests are producers and consumers whose interests are vested in the past and persist due to the entitlements obtained from authorities; for instance, tax exemptions or licenses to operate. Policies are considered actions by the public authorities.

\section{Debate about sustainable development}

The possibilities of obtaining higher income along with better environmental qualities and policies are widely discussed. This debate is well-summarized in Pearce and Turner (1990). On the extremes, the libertarians deny environmental threats for welfare, while ecologists pursue lifestyles using only basic technologies in order to prevent environmental collapse. Generally, both reject policies as ineffective and impeding their individual choice, albeit for different reasons. Aside 
NENTJES

of these extremes, the importance of policies for environmental qualities is widely acknowledged, although proposals and opinions differ about how to achieve changes for better environment and income. A typical environmentalist argument is that the consumption of fossil fuels, minerals, soil and other non-renewable natural resources causes irreversible degradation of environmental qualities. Furthermore, the development of substitutes for renewable natural resources, i.e., bioresources, as well as for capital and labor are sluggish or impossible in many cases. The impossibility of replacing natural capital by human capital and/or physical capital, i.e., "strong sustainability", leads to policies that aim at reducing income and consumption for the sake of better environment. This is debated by many economists who argue that the scarce natural resources can be substituted by less scarce resources if prices fully reflect the impacts of polluting activities. In this "weak sustainability" argumentation, policies can generate higher income and better environmental qualities due to the sustainable innovations if the price put on pollution is high enough.

The moderate positions in the debate on income and environmental qualities are rather fluid. For example, many adepts of weak sustainability argue that the threats to species require limited economic activities in nature protection areas because loss of biodiversity is irreversible. On the other hand, many advocates of the strong sustainability favour high taxes on emission of carbon dioxide $\left(\mathrm{CO}_{2}\right)$ as this provides incentives to develop substitutes for fossil fuels which are renewable energy and energy saving. As is discussed below, sentiments in that debate revolve but fluctuate depending on economic cycles: the environmentalist views are vocal when economies boom while the economist ones dominate during slumps. Herewith, the booms refer to periods of productivity upswing, and the slump to recessions and crises; they evolve every 40 to 60 years when the booms are driven by the basic innovations of steam, rail, electricity, chemicals and computers followed by stagnation in technologies. Beneath, highlights of this debate during last two centuries are presented. They focus on the United Kingdom (UK) and United States of America (USA) as this debate evolved mainly within the Anglo-Saks political tradition, while influencing global policies as these countries were leaders in the global economy and politics during last two hundred years. 
The foundation of environmentalist argumentation is usually traced back to the writings about population by Thomas Robert Malthus in the UK by the end of the $18^{\text {th }}$ century (Malthus 1826). Using observations of travellers to many countries during the $18^{\text {th }}$ century, Malthus theorized about the perpetuating cycles of growing population when higher incomes reduced mortality, which caused excessive uses of land, thereby declining harvests, food scarcity and mass starvation, followed by restoration of land and recovery of income. He called for policies that restrain income and fertility, although innovations in the agriculture generated food surplus in many European countries during his life time and thereafter. This Malthusian viewpoint is paradigmatic in the conventional environmentalist thought. Malthus and many of his contemporaries were disgusted by the industrial boom of late $18^{\text {th }}$ century based on steam machines and idealized the "stationary state" of rural life as expressed by John Stuart Mill, a leading liberal economist and philosopher of $18^{\text {th }}$ century in the UK (Mill 1985: 116). The ideal of rural communities with antiindustrial sentiments was attractive to the wealthy nobility but rarely to farmers who migrated to cities for a better living. The environmentalist ideal evolved into the mainstream environmentalist thinking during last century (Enzensberger 1982).

However, many non-conventional environmentalists successfully pursued safer work, wholesome food, proper housing, efficient energy, public sanitation, fire prevention, waste disposal and many other innovations in public service for better livelihood. Those sustainable innovations benefited people in cities who could afford them due to better income in industries, exceeding farming income significantly. Presently, such innovations are widely considered as basics in ethical production and consumption, whilst social entrepreneurship and ethical consumption are pursued (Enzensberger 1982).

During the economic boom driven by mass transport based on coal and steel in $19^{\text {th }}$ century in the UK, William Stanley Jevons argued that more efficient fuel use is countered by even larger total consumption entailing fuels scarcities, nowadays called the rebound effect (see Sorrell 2009). The rebound effects are widespread because cost-savings are often allocated in larger consumption, which can contribute to welfare but also wasteful consumerism. However, the scarcities of fuels did not appear because innovations enabled deeper and cheaper coal mining. In addition, oil 
and gas production expanded in the USA and Europe. This expansion was supported by authorities that created legal frameworks for the capital holdings, financed infrastructural works for production and distribution, and supported consumption of fuels with tax exemptions and other financial means, which are maintained and expanded until present (Rosenberg 1975). Entitlements for a monopoly position on markets were also given to the incumbent businesses, which created barriers of entry to innovators despite their better environmental and economic performances. For example, the entitlements to gas and oil producers for the monopoly in street lights in the late 1800s in the USA inhibited entry of electric lighting for several decades, despite numerous city fires caused by gas and oil explosions (DiLorenzo 1996). Despite these entitlements, the electric lights disseminated during 1900s when electricity became attractive business; there seems to be an analogy with present rivalry between fossil fuels and renewable energy. The monopoly entitlements are extended to various businesses using the argument that capital accumulation is necessary for large scale investments; this ideology of "natural monopoly" is a hoax to the public used for the public services and their privatization.

Debates about environmental policies emerged during the electricity boom early 1900s. Observations of damages caused by pollution from the expanding transport of fuels and electricity production brought Arthur Cecil Pigou in the UK to conclude that policies are needed to counter the harmful impacts of production on other interests (Pigou 1920). He advocated taxes on those so-called external effects and liabilities for damages caused by the polluters with compensations to victims. In his view, these financial instruments were more effective than regulations with norms. Environmental policies have been adopted across the world during last century, which triggered many innovations in pollution controls. Regulatory taxes and liabilities are rarely applied though widely advocated by economists as effective and efficient policy instruments because they are supposed to internalize the external environmental effect in market prices. On the contrary, focus on market negotiations in the neoclassic economics, which evolved into the mainstream economics late 1900s, opposed any environmental regulation. The basic argument is that the polluters and victims can resolve such externalities if they are free to negotiate about damages and compensations, and victims compensate polluters for their loss of 
income (Coase 1972). This libertarian viewpoint was introduced in policies during 1980s as self regulation in covenants. The principle that the polluters must pay is maintained, though it is regularly undermined; for example, through income compensation for pollution reduction.

The horrors of two World Wars in the 1 st half of the $20^{\text {th }}$ century was followed by a boom due to expansion of technologies for production of chemicals in 1950s and 1960s; for example fertilizers and plastics. In this period, the Malthusian population theory was rephrased into the metaphor of "Spaceship Earth", where the environmental qualities pose limits to all human activities (Boulding 1966). This idea is popularized as global boundaries called environmental carrying capacity. This idea inspired many studies on population dynamics in closed systems, i.e., population without external inflows of resources, while innovation will not enable an extension of the global boundaries. A well-known study concerns a computer simulation that shows global collapse of the economic-environmental system caused by resource scarcities and pollution (Meadows et al. 1972).

However, other scholars pinpointed that the Earth is not a closed system because it receives energy inflows from the Sun, which compensates dissipation of energy during production and consumption, while mined materials remain in products which can be recycled due to innovations (Georgescu-Roegen 1971). In this line of thought, possibilities for cleaner technologies in production and consumption became the topic of interest during the economic slump in the 1970s and 1980s, and focus in the debate shifted toward continuous global welfare growth with respect to environmental qualities called sustainable development. This is assumed to be attainable due to innovations that generate income and reduce pollution, which are underpinned as sustainable metabolism, tree-like business, green consumption and other metaphors that suggest compatibility of income and environmental qualities if far reaching pollution reduction is demanded.

The ICT boom during 1990s and 2000s was accompanied by ] arguments about the steady state economy (Daly, Cobb 1994), and de-growth, meaning decreasing global income with distribution of income for the sake of a better environment (Jackson 2011). However, the crisis after the financial collapse in 2008 illustrates that lower incomes do not necessarily reduce pollution because businesses spend 
less on pollution reduction and consumers spend more on basic goods which are usually more material-intensive than services, thereby more polluting per unit of income. An alternative idea was launched in the United Nations, called "green growth," which advocates policies that pursue eco-innovations or sustainable innovation (UNEP 2011). Meanwhile, environmental policies are widely accepted but opinions about sustainable development vary from wholehearted trust in applications of science and technology for the pollution prevention (Pinker 2018) to tedious manoeuvring between the limits posed by environmental qualities and societal well-being (Raworth 2017).

When reflecting on the debate about income and environmental qualities, it seems that similar arguments revolve within an amalgam of various political views. These views encompass the libertarian ideas about free market negotiations next to the liberal ones about civil engagement, the conservative opinions against technologies next to the socialist ones in favor of them. Such diversity of political opinions is presumably due to various social background of participants in the environmentalist advocacy. Estimates of these participants vary because there is no membership of the environmental advocacy. Nevertheless, the membership of the nature and environmental organisations is registered; in Europe more than 30 million can be found (EEB 2020) and in USA more than 10 million members (Statista 2020a). The diversity of the political opinions and participants foster the continuity of environmentalism but not necessarily coherent policies. Environmental policies in most countries are based on extensive regulations that are rarely enforced, while environmental expenditures are compared to fostering economic development; these policies are usually paper tigers.

\section{Autonomous technological change and environmental qualities}

Despite low attention to and expenditures for environmental issues compared to the income growth, pollution reduction has been achieved. Globally, during the last century, real annual income grew on average nearly twice as fast than the $1.2 \%$ annual average growth of the material consumption. In some countries, even a 
decrease in material consumption could be observed, i.e., pa process of decoupling and dematerialization of growth took place (Krausman et al. 2009). Moreover, innovations created a better liveable environment in many countries during last fifty years, though the environmental problems are far from resolved. Many hazards at work and in cities, measured by accidents, were mitigated during the 1970s. Waste, water and wastewater, measured by mass, were largely treated during the 1980s. Dirt, dust, smog and other health risks of local pollution, measured by health indicators. were reduced during the 1990s. Acidification of air, contamination of groundwater, losses of soil and other regional issues were contained during 2000s. Global issues of climate change, biodiversity loss and overconsumption are high on the policy agendas. All those improvements are realized along with a globally twice higher real income on average per person and better living measured by education and health for two additional billion people, but rarely by effective environmental policies. Hence, there are apparently forceful autonomous drivers for the improvements of environmental qualities.

A major driver of changes is the growth of services exceeding the growth in agriculture and industry. In effect, during the $20^{\text {th }}$ century, the share of agriculture in the global economy declined on average by -0.9 a year, the share of industries by $0.1 \%$ whilst the share of services increased by $0.2 \%$ a year. The service sector grew particularly fast during the second half of the century, when global income growth accelerated, resulting in a $26 \%$ larger global share of services in the global economy in 2000 compared to the year 1900 . Services covered $60 \%$ to $75 \%$ of the countries' economic value by 2010 compared to 35-45\% hundred years earlier (PBL 2020). Drivers of that sectoral growth are vividly discussed in economics, but consensus exists that higher productivity is the key for the growth, whereas productivity is largely driven by knowledge, in particular practical knowledge called know-how. Along with higher productivity in agriculture and industries, defined as higher value of output per area of land and per worker, services became more productive by output value per worker even though services employed more people during that century. Within services, the knowledge work expanded fast measured by the number of workers. Scientists, engineers, educators, managers, policymakers, as well as other experts, craftsmen and artists constituted a small group of specialists 
early 1900s. Their number grew to a quarter of all waged and non-waged workers in high-income countries hundred years later, whilst low-income countries catch up fast. Within knowledge work, know-how about production and deliveries grew particularly fast when enabled to use the theoretical knowledge, open social relations, inventive creations and other human capabilities and tools for solving complex problems. This know-how usually compounds labor, capital and knowledge resources for the engineering of natural resources into demanded, thereby valuable products (Mokyr 2002). Know-how generates productivity growth when it improves the resource use efficiency along with pollution reduction as cobenefit. These improvements constitute so-called autonomous technological change.

The mechanism of autonomous technological change is explained by looking into the box of a production function. A generic engineering model of production can be used in which the demanded output quality - a valuable product - is pursued with use of several input qualities of natural resources, given labor, capital and knowledge resources. Herewith, know-how is needed for the optimal use of natural resources in order to obtain the demanded product. When not done properly, the outcome may be negative from the economic and / or environmental point of view. In this model, loss prevention is a key factor for more effective use of resources, thereby a driver of autonomous technological change.

The role of know-how for the loss prevention can be illustrated with a hypothetical production function without any know-how, meaning that solely trial and error processes take place. This situation implies that the output qualities are a factorial function of input qualities (natural resources):

$$
N_{i}=N_{\circ} !+1
$$

For $N_{o}$, number of output qualities, $N_{i}$, number of input qualities.

Hence, an entrepreneur who aims to attain a demanded product with several natural resources without any know-how must consider numerous possible output qualities, but only one of them is the proper one. Imagine yourself cooking with unknown ingredients while aiming at a tasty dish. For example, with three input qualities of natural resources, seven possible output qualities must be considered $(3 * 2 * 1+1=7)$, while six of them are not-satisfactory. Four input qualities deliver twenty-five possible output qualities $(4 * 3 * 2 * 1+1=25)$, twenty-four of them being 
not satisfactory. And so on (Leeuwen 1989). Given that any production involves several dozens of natural resources, a myriad of non-demanded output qualities can be generated in a situation of negligible know-how. Each non-demanded output quality is a resource loss that can be remade into the desired quality with additional input, or is discharged into the environment as pollution. Both are costly. The remaking is costly to the producer and pollution is detrimental for society.

More know-how enables to generate a larger number of the demanded products and prevent some losses, thereby reducing pollution. For example, the energy output per fuel input increased from 4\% on average in 1900 to nearly 50\% nowadays (Smil 2017). This reduced losses of heat, dust and other emissions. In effect, more knowhow enlarges the number of desired products, generating income and reducing pollution, in turn decreasing the costs of pollution abatement in case of demand for pollution reduction. Improved loss prevention, often called cleaner production, generates income growth along with pollution reduction quasi-autonomously whilst higher demands for pollution reduction require better loss prevention, thereby more effective production which generates income, ceteris paribus. This is ignored, for example, in the advocacy of degrowth (Degrowth Declaration 2008). Know-how improves loss prevention but consumers demands can generate more complex production, meaning larger number input qualities, which requires more and diverse know-how. For instance, developing electric cars requires know-how about electricity and about ignition. Hence, the engineering performance in time can be conceptualized as a race between the growing know-how for loss prevention and more complex production due to the changing demands. Inter alia, some types of production hardly improve with much know-how, creating another challenge in addition to deficient know-how. For example, feed conversion in animals hardly changed despite much knowledge about animal metabolism and know-how about feeding. The feed conversion ratio of animals is the energy content of meat divided by all energy inputs needed for the production of meat. The energy content of meat is usually below ten percent (Statista 2020b).

Given the resource prices, larger know-how for loss prevention means higher costs, which may generate exponential improvements of the economic performance because it leads to provision of desired products and reduces costly discharges. Loss 
prevention is economically feasible when costs of know-how are compensated by the increased value of demanded products and the lower cost of discharges. It should be noted that demands for pollution reduction increase the costs of discharges, thereby making the use of know-how more attractive. If the benefit of the loss prevention exceeds the costs of know-how, innovation-rents are gained (a rent is net income from an asset). When the innovation-rents are allocated to knowledge work for new valuable novelties, or inventions are generated, this may lead to the appearance of innovations on the market. However, part of these innovation-rents is consumed by shareholders, another part is lost because due to inflation, while potential rents may disappear in financial loss when knowledge fails to invent or inventions fail in sales. Hence, loss prevention due to know-how reduces discharges of materials and energy into environment, which increases the production value due to more demanded products and reduces the costs of pollution, whilst the allocations of innovation-rents into novel valuable products can generate profitable innovations but they also risk failures. Combined valuable products, cost-saving pollution reduction, profitable innovations and risk of failures generate income growth along with pollution reduction as a side-effect of better know-how. This combination explains the autonomous technological change, called autonomous because emerges without specific external factors, through more effective production.

Given that the material and energy costs constitute only a part of total production costs, the scales of loss prevention and allocation of innovation-rents must be large in order to generate the income growth accompanied by pollution reduction. However, direct estimates of these scales are not possible because data on the product value and cost reduction of pollution due to loss prevention and the sales of all inventions are unavailable. An indirect estimate can be based on the comparison of indexed Gross Domestic Product (GDP) in USD and the materials use in tons. The scale is estimated with OECD data on member countries during, for the sake of this example, the period 2000-2010, because the OECD database on materials is most complete. The index base is year $2000=100$. The GDP index is corrected for indexed labor costs in order to exclude the impact of changing labor costs. If the indexed GDP increases after correction for labor costs and the indexed materials, an increase indicates there are innovation-rents due to loss prevention. In 
the OECD, the increase was on average about USD 4800 billion a year during those ten years (this number reflects the corrected GDP increase by USD 337 billion in 2001 compared to 2000, up to USD 11146 billion in 2010 compared to 2009). This is almost $11.7 \%$ of the USD 41000 billion GDP of the OECD members. If it is assumed that the allocation mechanism is globally similar to the OECD countries, considering that the OECD has a share of 59\% in global GDP, the global innovation-rents amount to USD 8200 billion, about $12.6 \%$ of global GDP. These data indicate a slower growth of material use than of GDP, and even a decrease of material input use in some countries (Krozer 2015).

\section{Opportunities for sustainable innovations due to induced innovations}

Technological change can be induced by the specific demands of public authorities and consumers. These demands generate opportunities for innovators if they can outperform rival incumbent businesses by prices and qualities. However, the opportunities do not guarantee sales of innovations. The demands provide opportunities for sustainable innovations when the authorities aim to prevent harms to health and nature, or consumers express interest for their well-being and work performance. The former can achieve its aim by regulation, the latter by purchases.

High environmental qualities are particularly important for knowledge work, not only for the well-being of the individuals, but also due to its potential positive impact on knowledge-worker performance. The line between work and leisure is typically blurred for most knowledge work. Whilst knowledge work rarely performs when it is bound to agriculture or industry, it flourishes due to social interactions that generate formal and informal exchanges of the professional knowledge. These knowledge spillovers emerge when people of various interests interact in spacious, tranquil, lush public spaces. These spaces are found in rural areas without sufficient density of various people and in quasi-rural environment with high diversity of people in parks, campuses, terraces and suchlike urban creations of meeting points.

The regulatory demands refer to direct regulations in the form of licenses and performance standards, as well as indirect regulations such as taxes, subsidies and 
NENTJES

other financial instruments. They address issues in the process of extraction of natural resources - safety in mines, liability for oil and gas spills, obliged reforestation and so on - and pollution controls in all business sectors and in households. Market opportunities in the extractions of natural resources cannot be estimated directly because data on available technologies is deficient. The indirect estimates based on the rents from extraction of natural resources are indicative; these rents are sales of commodities minus costs of extraction. Assuming competition in the sales of commodities and extractions technologies, an increase of rents indicate the market value that can be accrued when better technologies are demanded. The estimated rents in extraction of coal, oil, gas, forest and minerals are based on the World Bank database for the period 2004-2012. Fluctuations in data after the financial crisis in 2008 make it necessary to shorten the period to 2004-2008. The annual average increase in rents was USD 1100 billion a year. Furthermore, markets in renewable energy, energy efficiency and water supply should be added to the resource extractions. These are estimated to be about USD 400 billion a year (Copenhagen Cleantech Cluster 2012). Hence, market opportunities for the sustainable innovations in the extraction of natural resources including energy are about USD 1500 billion a year, i.e., 2.3\% of global GDP in 2010. Data about global pollution controls are not available. Most complete data can be found for the 28 member states of the European Union (EU). The estimated rent is on average about USD 200 billion annually for the period 1995-2010, i.e., 1.5\% of the EU GDP in 2010. If this percentage would apply to the global scale, assuming that pollution relates directly to the countries' GDP, about USD 1300 billion a year is spent globally on the pollution controls. It should be noted that countries with materialintensive, polluting industries might have a higher percentage than that $1.5 \%$ of GDP average in the EU (e.g., Australia and Canada), while the percentage for EU countries with much services as well as low-income countries is lower. In sum, the regulations of environmental qualities generate yearly about USD 2800 billion market opportunities for sustainable innovations, approximating $3.7 \%$ of global GDP.

As mentioned, the consumers demand of attributes of environmental qualities is reflected in purchases. These purchases refer to qualities within the cultural 
expressions of nature. For example, 'natural' because made of bioresources, 'fair trade' because paid to indigenous community, 'ecological' because low-pollution, 'animal friendly' because allowing space, and suchlike consumptive cultural purchases and uses of nature; herewith, this type of consumables are labelled as natural blends. For convenience, the natural blends are divided into three markets with sufficient distinction to avoid double counting: products that express ethical purchases because they express the consumers responsibilities for nature and people; services that provide experience of nature on locations; and images of nature in media, culture and education. All these markets provide opportunities for sustainable innovations.

The global estimates are only indicative because of poor data. Data on all ethical purchases can only be found for the UK, but even these data vary from USD 54 billion (Co-op 2019) to USD 106 billion (Triodos 2017) for nearly the same year due to difference in the definition of the purchases. Scaling up of the UK data to the global level would show a unreliably large global market. It has been suggested that about 3\% of the consumer purchases in the EU can be considered as ethical purchases (Vringer et al. 2013). These purchases per capita are rather high in Austria, Denmark, Switzerland, Germany and the UK, while being lower in other EU countries. Assuming that $2 \%$ of the disposable consumer expenditures in the OECD countries and $1 \%$ in the non-OECD countries are spent on ethical purchases, the global market opportunities for the sustainable innovations related to ethical purchases are about USD 700 billion annually (1.0\% of global GDP in 2010). Visits to and holidays in nature is becoming popular, and ecotourism is a growing business. Inquiries into the tourist destinations suggest that nearly USD 600 billion is spend on the ecotourism annually, showing faster growth than international tourism as a whole (Balmford et al. 2015). Even larger expenditures are made on domestic tourism for health, wellness, and nature (Krozer, Lordkipanidze 2018). Assuming arbitrarily that one third of the stated preferences in international ecotourism is revealed because spent in the nature resorts, which means excluding mixes of leisure, culture and other forms of tourism, the global market for sustainable innovations in ecotourism exceeds USD 200 billion per year. This is 
NENTJES

excluding the domestic expenditures on the ecotourism, which can double that estimate. This number amounts to $0.3 \%$ of global GDP in 2010.

Opportunities also emerge in media, education and other cultural activities, but data are unavailable. If it is assumed that the above mentioned 40 million members of environmental organizations in Europe and USA spend on their consumption of leisure, culture, education directly in relation to the natural blends, the global market opportunities for sustainable innovations in cultural expressions are about USD 42 billion $(0.07 \%$ of global GDP). This number is probably an underestimation of all expenditures on nature in media, because many non-members are also passionate consumers of the natural blends in media. Globally, about 800 billion market opportunities exist for sustainable innovations due to the natural blends, which is about $1.4 \%$ of global GDP (Krozer 2015).

While data lack, an indication of the size of the total global market opportunities for the sustainable innovations is more that USD 3600 billion a year. It is mainly consumers demands that create opportunities, as ethically purchases are on the rise ones. Although the growing consumer demands for natural blends may justify far reaching regulatory measures, regulations have been relaxed in the EU and USA during last decades. This seems to be beneficial to the polluters, but they risk losses of market shares to competing sustainable innovators. While the market opportunities due to the regulatory demands decrease in the USA and Europe, they expand in many Asian countries. Market losses can be observed in renewable energy because the Chinese solar producers outcompete the European ones, in the electric cars because Japanese outcompete the USA producers. Another example is bioresources, because Indian producers take lead in bioplastics. However, links between the regulatory demands and sales of innovations can be disputed. Moreover, entitlements to the polluting business through lax policies can deplore sustainable innovations. For instance, in the Netherlands producers of pollution control equipment were trailblazing in many areas due to stringent demands during 1970s and 1980s, but they lost market shares from 1990s on when self regulation was pursued under various political composition of the government (Krozer 2008). 


\section{Barriers posed by present policies}

Regarding large and growing demands for environmental qualities which create market opportunities for the sustainable innovations, fast dissemination of technologies that reduce pollution can be expected. However, complaints about impediments are too notorious to be dismissed as soundbites of grumpy technology producers. Several impediments related to information deficiencies can be pinpointed; for example, trade-offs between functional performance and the environmental performance of supplied technologies; lack of interest and deficient knowledge of adopters about the environmental issues; difficulties to handle profitability and environmental qualities in purchases because these goals can collide; deficient links between demands of authorities and adopted sustainable innovations, and others. All these impediments related to imperfect information about the sustainable innovations can be relevant in addition to the conventional risk of adopting innovations because of technical and managerial uncertainties during uses.

The barriers to entry for the sustainable innovators posed by authorities implies impediments for the dissemination of novelties because policies impede sales and operations of these innovators on different markets. Here, only tangible barriers to entry are addressed; whether they are on purpose, or by incidence is not assessed. In particular, the financial policy support for the incumbent interests whose activities are polluting is estimated. The financial policy support creates barriers to entry because incumbents' interests are rival to the sustainable innovators, and they can act at lower costs. In this discussion, focus is only on a few well-measurable global instruments in monetary terms. More barriers can be found when considering financial instruments on the country level. For sure, more research on the barriers to entry for the sustainable innovators is needed because removing such barriers can be decisive for progress toward sustainable development.

The policy support in energy addresses businesses that produce energy resources, as well as businesses and households that consume energy products and services; for example, gasoline and electricity. This support is by and large in favor of fossil fuels. Herewith, subsidies are expenditures from the public budgets. These 
are statistically measured, among others by the International Energy Agency. In addition, much larger tax exemptions, credit facilities and price guarantees are dedicated to support the producers and consumers of fossil fuels which do not appear in the budgets, thereby miss democratic control and societal scrutiny. Furthermore, agreements with large energy consumers in businesses about lower energy taxes and price discounts make energy-efficiency unattractive to them, although the savings per unit energy consumption are usually cheaper in large installations than in small ones. Such agreements also undermine fair play in competition and obstruct the income distribution because small business and households must pay higher prices in order to compensate for the lower costs of large energy consumers. A comprehensive assessment of the financial support policy, excluding the tax and price agreements with large energy consumers, was carried out by the International Monetary Fund (IMF). This study indicates that abolishing this support policy would reduce government expenditure yearly aby bout USD 2900 billion. Most of this support is aimed at reducing the price of fossil fuels (Coady et al. 2015). Assuming that $80 \%$ of that support is dedicated to fossil fuels, this makes USD 2175 billion per year, which is about one third on the global market value of energy consumption. The prices and tax discounts for large energy consumers approximate USD 180 billion a year in the EU, but they are unknown globally (Krozer 2015).

Agriculture receives large subsidies which are environmentally harmful, because they are mainly allocated to support larger use of chemicals and larger output per hectare, which in turn mainly supports large-scale farming and industrial businesses. That financial support in the EU and USA is estimated to exceed USD 430 billion a year, excluding public financing for restructuring of farmland which generates large scale agricultural units but impedes ecologically sound management (Worldwatch 2014). In addition, policies support consumption of foods through tax exemptions, which can encourage wasteful food consumption in high-income countries.

Infrastructure is mainly paid from the public sources; nearly 97\% of USD 2600 billion global annual investment is covered by the public expenditures (Dobbs et al. 2013). However, the infrastructural works deplore environmental qualities on site and generate activities that cause harms to the surrounding. Moreover, the 
construction of infrastructure are often more expensive than planned, many investments are unnecessary because they generate low or negative economic effects after the realization. It is shown that much infrastructure would not be built when these works would be financed from private resources, because they are costly and risky compared to many other socially beneficial investments (Flyvbjerg et al. 2003). My prudent guess is that $20 \%$ of that policy support is wasteful, which means USD 520 billion a year.

Expropriation of land from local communities for intensive agriculture, forestry and mining is supported by authorities through concessions to businesses for use of land, neglecting the pre-existing and customary local land rights. Such concessions degrade environmental qualities when the extensive use by local communities is replaced, while these communities lose their source of income. Such concessions, guaranteed by authorities as entitlements to businesses, were assessed for 22 emerging economies with the land coverage of 9 million hectares. These concessions are valued at USD 5190 billion (Leon et al. 2013). If a 10\% linear depreciation of these rights is assumed, the annual value of public support for these concessions is about USD 519 billion a year.

The total public financial support for the polluting, incumbent interests is estimated at USD 3800 billion a year, which is about 5.8\% global GDP. However, it is presumably larger if more detailed assessments on the countries' levels would be carried out. The numbers show that public support to the harmful incumbent interests is larger than the global market opportunities for sustainable innovations. Moreover, much public support is accrued by large-scale firms, which implies that the shareholders obtain benefits rather than small and medium scale enterprises. This reduces competition, hampers innovations and enhances shifts of income from labor to large holders of capital.

In theory, the pace of pollution reduction can be considered a function of the allocated innovation-rents for valuable products, subject to the market opportunities for sustainable innovations, $d$, versus the barriers of entry, s. Hence, the factor $d / s$ indicates the decoupling rate due to the induced technological change, meaning the rate at which the incomes grow faster than pollution. This can be formally written as follows: 
NENTJES

$$
\Delta i=\Delta v_{a}^{d / s}
$$

Given that the global market opportunities for sustainable innovations approach USD 3600 billion a year, and the barriers of entry posed by the financial support policy to the harmful incumbents exceed USD 3800 billion a year, the decoupling rate of induced technological change is below unity. This implies slower technological change for pollution reduction than the one induced by demand. The observed decoupling is generated despite obstructions by the public authorities, thanks to autonomous technological change and better know-how. Hence, faster technological change for sustainable development and higher effectivity of production can be expected in the countries that eliminate their policy support to incumbent consumers and producers.

\section{Concluding remarks}

Possibilities for innovating for renewable energy, agroforestry, recycling and other sustainable innovations were discussed in this paper with regard to autonomous technological change, induced technological change and barriers to entry for innovations, in the context of debates about income growth and environmental qualities. In these debates, which has been ongoing for two centuries, the environmentalists typically assume that economies are locked-in within destructive technological patterns in the closed system of Earth. However, the Earth is an open solar system and technologies, although imperfectly, enable maintenance of environmental qualities. Mainstream economics assumes that market competition is the rational ideal, and authorities / governments are independent entities pursuing the common good. However, market participants seek rents from entitlements obtained from authorities that rather support their private interests that execute their power. Various arguments in the debate are inconsistent with observations, making the effectivity of policies for sustainable innovations disputable.

Quasi-autonomous changes have evolved during the last century, when the global economy shifted from agriculture and industries to services. Services makes more intensive use of knowledge work increased, in particular know-how. The 
growing know-how enabled more effective production, which means more desired products per resources input along with pollution reduction as a side-effect of the effectivity improvements. More effective production generated innovation-rents that are partially allocated in the innovative, higher value activities. The economic benefit was estimated in this paper to approach $12.6 \%$ of global GDP in the first decade of the $21^{\text {st }}$ century.

Besides for a good living, people also demand environmental qualities because their performance needs social interaction in a good environment; in particular, in the case of knowledge work. These demands generate market opportunities for sustainable innovations, which can be realized if they provide qualities and prices that are superior to existing goods and services. These market opportunities are induced by the regulatory and consumer demands. The regulatory demands aim to contain losses in extraction of the natural resources and to reduce pollution. Based on the estimates shown above the regulatory opportunities for sustainable innovations are estimated to exceed globally USD 2800 billion per year, about 3.7\% of global GDP. In addition, global market opportunities emerge due to consumer demands for ethical purchases, ecotourism and images of nature. These cultural expressions of environmental qualities generate about USD 800 billion a year, 1.4\% of global GDP. Hence, global market opportunities for sustainable innovations exceed USD 3600 billion a year, 5.1\% of global GDP. This provides a strong incentive for induced technological change based on dissemination of sustainable innovations.

However, sustainable innovators face high barriers of entry posed by authorities, because of support of current business interest, being harmful to environmental qualities. In this paper, it was estimated that solely the financial support for fossil fuels, large scale agriculture, wasteful infrastructure and unfair concessions in the exploitation of minerals exceeds USD 3800 billion a year, which is about 5.8\% global GDP. The barrier of entry caused by this financial support for existing producers using polluting technologies is larger than the induced technological change created by the demand for sustainable innovations. This finding indicates that globally the public authorities obstruct sustainable innovations, thereby impede progress toward sustainable development. 
Possibilities for sustainable innovation are developed but they are obstructed by policy support for the environmentally harmful incumbent interests. Shifting this public support towards capacity building and income guarantees for development and dissemination of the sustainable innovations amalgamates various social interests, because it enhances productivity and foster environmental qualities through experimenting and business start-ups.

\section{Acknowledgment.}

I appreciate cooperation with Springer in publishing the book Theories and Practices on Innovating for Sustainable Development and using materials from the book in this paper.

\section{Conflict of interest}

There are no conflicts of interests involved in this publication - author copyrights remain with the author of this paper.

\section{References}

Ashford N.A. (1996), The influence of information-based initiatives and negotiated Environmental Agreements on Technological Changes, in: Voluntary approaches in environmental policy, Carraro C., Lévêque F. (eds.), 1st ed., Kluwer Academic Publishers, Dordrecht, pp. 137-150.

Balmford A., Green J.H.M., Anderson M., Beresford J., Huang C., Naidoo R. (2015), Walk on the wild side. Estimating the global magnitude of visits to protected areas, "PLoS Biology", vol. 13 no. 2, https://doi.org/10.1371/journal.pbio.1002074 [03.10.2020].

Boldrin M., Levine D.K. (2004), Rent-seeking and innovation, “Journal of Monetary Economics”, vol. 51 no. 1, pp. 127-160.

Boulding K.E. (1966), The economics of the coming Spaceship Earth, Johns Hopkins University Press, https://www.semanticscholar.org/paper/The-Economics-of-the-Coming-Spaceship-Earth-

Boulding/88cb333c9c7ebb5d852c037372eccc39c12ca691 [06.05.2020].

Coase R. (1972), The problem of social cost, reprint in: Economics of the environment, selected readings, Dorfman R., Dorfman N.S. (eds.), 1st ed., W.W. Norton \& Company, New York, pp. 142171.

Coady D., Parry I., Sears L., Shang B. (2015), How large are global energy subsidies? Report WP/15/105, International Monetary Fund, New York.

Co-op (2019), Twenty years of ethical consumerism, https://www.ethicalconsumer.org/researchhub/uk-ethical-consumer-markets-report [11.09.2020]. 
Copenhagen Cleantech Cluster (2012), The global Cleantech report 2012, Danish Industry Foundation, http://www.cleancluster.dk/wp-content/uploads/2017/06/594258a4eb825.pdf [27.12.2020].

Daly H.E., Cobb J.B. (1994), For the common good, 2nd ed., Beacon Press, Boston.

Declaration (2008), Declaration of the Paris 2008, Economic De-Growth for Ecological Sustainability and Social Equity Conference, Paris, April 18-19, 2008.

DiLorenzo T.J. (1996), The myth of natural monopoly, "The Review of Austrian Economics", vol. 9 no. 2, pp. 43-58.

Dobbs R., Pohl H., Lin D., Mischke J., Garemo N., Hexter J., Matzinger S., Palter R., Nanavatty R. (2013), Infrastructure productivity. How to save $\$ 1$ trillion a year, McKinsey Global Institute, https://www.mckinsey.com/ /media/McKinsey/Industries/Capital\%20Projects\%20and\%20Infrastructur e/Our\%20Insights/Infrastructure\%20productivity/MGI\%20Infrastructure_Executive\%20summary_Jan $\% 202013$.ashx [27.12.2020].

EEB (2020), https://eeb.org/membership/about-membership/ [22.12.2020].

Enzensberger H.M. (1982), A critique of political ecology in: Hans Magnus Enzensberger. Critical Essays, Grimm R., Armstrong B. (eds.), Continuum, New York, pp. 186-223.

Flyvbjerg B., Bruzelius N., Rothegaster W. (2003), Megaprojects and risks, 1st ed., Cambridge University Press, Cambridge.

Georgescu-Roegen N. (1971), The entropy law and the economic process, https://www.scribd.com/document/267519123/The-Entropy-Law-and-the-Economic-Process-by-

Nicholas-Georgescu-Roegen-pdf [03.05.2020].

Jackson T. (2011), Prosperity without growth, 2nd ed., Earthscan, New York.

Krausmann F., Gingrich S., Eisenmenger N., Erb K.-H., Haberl H., Fischer-Kowalski M. (2009), Growth in global materials use, GDP and population during the 20th century, "Ecological Economics", vol. 68 , pp. 2696-2705.

Krozer Y. (2008), Innovations and the environment, Springer, London.

Krozer Y. (2015), Theories and practices on innovating for sustainable development, Springer, Heidelberg, Dordrecht.

Krozer Y., Lordkipanidze M. (2018), Bioresources for cultural services, in: Economics of bioresources, Krozer Y., Narodoslawsky M. (eds.), Springer, Dordrecht, pp. 195-206.

Krozer Y., Nentjes A. (2006), An essay on innovations for sustainable development, "Environmental Science", vol. 3 no. 3, pp. 163-174.

Krozer Y., Nentjes A. (2008), Environmental policy and innovations, "Business Strategies and the Environment", vol. 17 no. 4, pp. 219-229.

Krueger A.O. (1974), The political economy of the rent-seeking society, "The American Economic Review", vol. 64 no. 3, pp. 291-303. 


\section{TOWARDS SUSTAINABLE INNOVATIONS - ESSAY IN MEMORIAM OF ANDRIES NENTJES}

Kuipers S.K., Nentjes A. (1973), Pollution in a neo-classical world: the classics rehabilitated?, "The Economist", vol. 121 no. 1, pp. 52-67.

Leeuwen C. van (1989), De organisatie van milieu en veiligheid in een grote onderneming, in: Milieu en innovatie, Vollebergh H. (ed.), Wolters Noordhoff, Groningen, pp. 155-176.

Leon de R., Garcia T., Kummel G., Munden L., Murday S., Pradela L. (2013), Global capital, local concessions. A data-driven examination of land tenure risk and industrial concessions in emerging market economies, The Munden Project Ltd., http://exchange.growasia.org/system/files/Global\%20Capital\%2C\%20Local\%20Concessions\%20A\%2 0Data-

Driven\%20Examination\%20of\%20Land\%20Tenure\%20Risk\%20and\%20Industrial\%20Concessions\% 20in\%20Emerging\%20Market.pdf [27.12.2020].

Malthus T.R. (1826), An essay on the principle of population, vol. 1, 6th ed., https://oll.libertyfund.org/titles/malthus-an-essay-on-the-principle-of-population-vol-1-1826-6th-ed [02.05.2020].

Meadows D.H., Meadows D.L., Randers J., Behrens III W.W. (1972), Limits to growth, A Potomac Associates Book, Washington D.C., http://donellameadows.org/the-limits-to-growth-now-available-toread-online/ [02.05.2020].

Mill J.S. (1985), The principles of political economy, Penguin Classics, New York.

Mokyr J. (2002), The gift of Athene, Princeton University Press, Princeton.

Murphy K.M., Shleifer A., Vishny R.W. (1993), Why is rent-seeking so costly to growth?, "The American Economic Review", vol. 83 no. 2, pp. 409-414.

PBL (2020), Netherlands Environmental Assessment Agency, Historic Database on Global Environment, HYDE https://themasites.pbl.nl/tridion/en/themasites/hyde/index.html [25.10.2020].

Pearce D.W., Kerry Turner R. (1990), Economics of natural resources and the environment, Pearson Education, Harlow.

Pigou A.C. (1920), The economics of welfare, 1st ed., MacMillan, London.

Pinker S. (2018), Enlightenment now. The case for reason, science, humanism and progress, Penguin Books, Random House.

Raworth K. (2017), Donut economie, Nieuw, Amsterdam.

Rosenberg N. (1975), Technological innovation and natural resources. The niggardliness of nature reconsidered, in: Perspectives on technology, Rosenberg N. (ed.), Cambridge University Press, Cambridge MA, pp. 229-259.

Sen A. (2009), The idea of justice, 1st ed., Penguin Books, London.

Schumpeter J.A. (1989), Business cycles, 4th ed., Porcupine Press, Philadelphia.

Smil V. (2017), Energy and civilization. A history, MIT Press, Cambridge MA. 


\section{Yoram KROZER}

Sorrell S. (2009), Jevons' paradox revisited. The evidence for backfire from improved energy efficiency, "Energy Policy", vol. 37 no. 4, pp. 1456-1469.

Statista (2020a), https://www.statista.com/statistics/190934/membership-of-national-environmentaland-conservation-organizations-2005-2006/ [22.12.2020].

Statista (2020b), https://www.statista.com/statistics/254421/feed-conversion-ratios-worldwide-2010/ [22.12.2020].

Triodos Bank (2020), Ethical consumer markets report 2017, https://www.ethicalconsumer.org/sites/default/files/inline-files/ec\%20markets\%20report\%202017.pdf [11.09.2020].

UNEP (United Nations Environment Programme) (2011), Towards a green economy. Pathways to sustainable development and poverty eradication, UNEP, New York.

Vringer K., Vollebergh H., Soest van D., Heijden van der E., Dietz F. (2013), Dilemma's rond duurzame consumptive. Een onderzoek naar het draagvlak voor verduurzaming van consumptive, Planbureau voor de Leefomgeving, Bilthoven.

WCED (World Commission on Environment and Development) (1987), Our common future, 1st ed., Oxford University Press, Oxford.

Worldwatch Institute (2014), http://www.worldwatch.org/agricultural-subsidies-remain-stapleindustrial-world-0 [09.08.2014]. 